Relations industrielles

Industrial Relations

\title{
Keenoy, Tom and Di Kelly, The Employment Relationship in Australia
}

\section{Braham Dabscheck}

Volume 51, numéro 3, 1996

URI : https://id.erudit.org/iderudit/051126ar

DOI : https://doi.org/10.7202/051126ar

Aller au sommaire du numéro

Éditeur(s)

Département des relations industrielles de l'Université Laval

ISSN

0034-379X (imprimé)

1703-8138 (numérique)

Découvrir la revue

Citer ce compte rendu

Dabscheck, B. (1996). Compte rendu de [Keenoy, Tom and Di Kelly, The Employment Relationship in Australia]. Relations industrielles / Industrial Relations, 51(3), 607-609. https://doi.org/10.7202/051126ar

Tous droits réservés (C Département des relations industrielles de l'Université Laval, 1996
Ce document est protégé par la loi sur le droit d'auteur. L'utilisation des services d'Érudit (y compris la reproduction) est assujettie à sa politique d'utilisation que vous pouvez consulter en ligne.

https://apropos.erudit.org/fr/usagers/politique-dutilisation/ 
Despite such general statements which may be misconstrued by the reader, Moggridge's intention was primarily to describe details of Keynes's life and not to provide a rigorous analysis of his works. Without question, the author has accomplished the former objective admirably.

MARIO SECCARECCIA University of Ottawa

\section{The Employment Relationship in Australia}

by Tom KEENOY and Di KELLY, Sydney, Harcourt Brace, 1996, p. xii +427 , ISBN 072953314 X (paperback).

Two conditions are necessary for the existence of a discipline. The first is a subject matter to be studied; and the second, persons able to conduct research and scholarship in the said subject matter. In the "area" known as industrial relations it is clear that the first condition is satisfied. Industrial relations involves the study of the interactions of the various individuals, groups and organisations involved in or interested in the world at work. In recent years the discipline of industrial relations has been subjected to attacks and/or takeovers from persons working in organisational behaviour and human resource management. Industrial relations can easily fend off such attacks by producing high level research and scholarship.

Tom Keenoy and Di Kelly have published an industrial relations textbook entitled The Employment Relationship in Australia. In their introduction they say "we seek to establish a disciplined framework to understand what happens in industrial relations" (p. 13). It might be interesting to explore what is involved in producing a "disciplined" textbook. The essential function of such a work is to introduce students to the major issues and ideas associated with the discipline; and to inculcate in students an appreciation for and understanding of the high standards involved in research and scholarship. Such a text should use, and dem. onstrate the use of, primary sources; clearly express and examine the position of major thinkers/writers; examine the evolution of ideas and practice within the discipline and foster critical thought and analysis.
The Employment Relationship in Australia fails to meet these various criteria. Other than for reproducing a few sets of tabulated data (whose authenticity the authors do not trust because of the airconditioned comfort that the collectors of statistics enjoy - see page 52) the authors make sparse use of primary source data. In examining major developments which have occurred in Australian industrial relations the authors do not quote from major documents, nor the decisions of courts or tribunals. Students will have to look elsewhere for citations of such basic research materials. In addition, the authors rarely engage with the literature, particularly theoretical writings. There is hardly any attempt to present and examine the position of various writers in the tradition of what is usually provided in textbooks. The Employment Relationship in Australia is an a-theoretical work.

On page 168 the authors state "social scientific predictions have generally proved to be marginally less accurate than those of astrologers". This is a most interesting statement given that one of the authors has edited a work on research and method, with a second edition forthcoming (see Diana Kelly (ed.) Researching Industrial Relations: Methods and Methodology, Australian Centre for Industrial Relations Research and Teaching, Monograph No. 6, University of Sydney, December 1991).

The Employment Relationship in Australia is written in the style of a person talking to friends in a pub or bar. It is full of colloquialisms and apparently 
whimsical turns of phrase. It contains expressions like "blustering employers ... bleating trade unionists ... [and] baleful politicians" (p. 13), "the slippery surfboard of life" (p. 65), "changemasters" (p. 73), "hobgoblin unionists" (p. 78), "a snakeeyed labour sub-contractor" (p. 88), "Ms Nice Guy" (p. 118), "policy-makers" grey cells", "mind boggling complexity" (p. 169), "transient pollies" (p. 184), "law merchants" (p. 223), "the great wheelchair of industrial life" (p. 292), "talking heads" (p. 304), "bureaucratic mincing machines" (p. 319) and "revolting workers" (p. 390).

The authors also provide readers with a series of apparently wise, almost philosophical observations concerning life and industrial relations. For example on page 24 they state "Most people would rather have a tooth extracted than pursue official statistics". We are also informed that "After all, if there is nothing else, money is a valuable and very flexible resource of which most of us are always short" (p. 75); and that the "common law ... is anything but vulgar" (p. 101). In describing the operation of tribunals Keenoy and Kelly state that "some lawyers have made a cool living from these muddy waters" (p. 151). They also point out that "No cows have yet complained of the unspeakable processes to which they are subjected before being transformed into hamburgers" (p. 177); "Intellectual property rights may sound about as exciting as watching grass grow" (p. 202); "the history of management thought is littered with the remains of new blue whiteners" (p. 205); and that "transforming an organisational culture is not like changing your trousers" (p. 207).

On page 20 the authors state:

sixteen ... is spent thinking about sex. By twenty-five we are constantly exhausted by the consequences of sex; babies never seem to sleep when we do. Being thirty-something can be very trying - particularly for women - for the demanding work of bringing up children and running a home eat up all our free time. At forty-five we breathe again, only to discover that life has passed us by. This precipitates a mid-life crisis which makes us question whether, having regained our freedom, it is actually worth having since we have forgotten what to do with it. By the time we are fifty-five along come grandchildren and our existential neurosis is replaced by babysitting, the definitive evidence of our mortality. In between times we suck on the reviving blandishments of the leisure society: barbecues twice a week, sport on TV and - if you are male and lucky - Long Service leave to find out why it was all worth it.

Reference is also made to a "Lombard" which the authors state "is one of those acronyms devised to describe the likes of the white-shoe brigade of the 1980s. It refers to an advanced form of Yuppiedom: Lots-Of-Money-But-AReal-Dork (or something very close to that". (p. 35). On page 43 the authors create a character (as an ideal type) who is accused of "being possessed of a variety of sexual deficiencies". We are also told "Size, as they used to say in the 1960s, is not important" (p. 215). In discussing issues associated with bargaining the authors state "we negotiate with our children - Iollies often being the means of securing compliance; in our marriage relations - where the currency is sometimes sex and emotional blackmail" (p. 249, also see p. 361).

The Employment Relationship in Australia contains a number of contradictions. In their concluding chapter the authors refer to "the many industrial relations and management texts which address the problem of how to create and maintain harmonious relations between employer and employee". They then add, in brackets, "Such themes have been carefully avoided in this book" (p. 387). Four pages later they state "Indeed, the unstated theoretical issue which this book has addressed constantly is the question of how the actors create and maintain social order in the employment relationship" (p. 391/92). On page 259 the 
authors state "The majority of bargaining ... does not take place behind closed doors". Four pages later they do 180 degree turn in saying that "Normally, all negotiations are held behind closed doors" (p. 263).

On page five the authors state "the Fraser administration tried to control wages through wage indexation". On page 159 they say the Australian Conciliation and Arbitration Commission introduced wage indexation at the behest of the Whitlam Labour government. On page 184 it is stated that "the last time government pretended it was leaving control over wages to the impartial magic of the market - [was] under the Fraser administration of $1975-83 "$. For the record, wage indexation operated in Australia from April
1975 to July 1981 . The Commission introduced this centralised, non-market based, system in response to problems of the mid-1970s. With the exception of one case, the Fraser government steadfastly opposed the various increases granted by the Commission.

The Employment Relationship in Australia does not meet normal standards of discipline and rigour which is required for a textbook. Students should not be exposed to this work. Its publication has diminished the reputations of the authors, the publisher and the discipline of industrial relations.

BRAHAM DABSCHECK University of New South Wales

\section{LA REPRÉSENTATION Miroir ou mirage de la démocratie au travail?}

Actes du XLIX ${ }^{\mathrm{e}}$ congrès des relations industrielles de l'Université Laval

Préface, Gilles LAFLAMME - Introduction, Michel AUDET, Esther DÉOM, Anthony GILES et Alain LAROCQUE - La représentation en relations industrielles : perspectives et prospective, Gregor MURRAY - PREMIERE PARTIE : BILAN ET EXPÉRIENCES DE REPRÉSENTATION AU QUÉBEC - La démocratie et son application en milieu de travail, Rodrigue BRILLANT - Comment les organisations syndicales ont-elles vécu la représentation?. Claude DUCHARME - L'accréditation et la négociation sectorielles, Robert SAUVÉ - La représentation démocratique au sein de l'administration publique $d u$ Québec, Fernand MORIN - La concertation nécessaire: deux expériences québécoises. Jean-Guy FRENETTE - De la confrontation au partenariat, Michel GIRARD et Bertrand HARVEY - DEUXIĖME PARTIE : L'AVENIR DE LA REPRÉSENTATION - Forum - Qui va parler en notre nom ?, Claudette CARBONNEAU - La représentation: vébicule de la démocratie au travail, René BEAUDRY - Les systèmes institutionnel et non institutionnel de représentation, Ghislain DUFOUR - L'administration Clinton et la réforme du droit du travail, Elaine BERNARD - Les relations industrielles mexicaines et la démocratie dans le contexte de l'ALENA, Maria Lorena COOK - Les structures de représentation en Amérique du Nord et le nouveau contexte économique et politique, Anthony GILES - Division du travail, relations professionnelles et implication du personnel, Benjamin CORIAT.

En vente chez votre libraire ou auprès de Distribution de livres Univers 845, rue Marie-Victorin, Saint-Nicolas (Québec) GOS 3LO tèl. (418) 831-7474 1-800-859-7474 têlêc. (418) 831-4021 